\title{
FLOOD RISK MODELLING OF STULIANSKY STREAM IN LOPÚCHOV VILLAGE, SLOVAKIA
}

\author{
RASTISLAV FIJKO, MARINA ZELEŇÁKOVÁ \& IBRAHIM ALKHALAF \\ Institute of Environmental Engineering, Technical University of Košice, Slovakia.
}

\begin{abstract}
The paper focuses on the modelling of water flow in open channel of Stuliansky stream in the village Lopúchov, situated in the north of Slovakia. It presents: I) the proceeding of the model development in HEC-RAS; II) the creation of flooded areas in ArcGIS; III) the flood risk assessment by Cost Benefit Analysis (CBA). We will point out the modelling methodology with emphasis to collection of the data and their relevance for flood risk modelling of study area. From the developed model, it is possible to determine the maximum water level in each river profile, the extent of flooding, flow rate, or flow velocity in a particular profile, taking into account the proper Manning roughness coefficient for each profile. The benefit of this work is the definition of flooded area in the municipality Lopúchov in the eastern Slovakia. The 3D model of a given territory is created at Geographical Information System (GIS) platform and it shows the flooded part of the urban area in village Lopúchov, caused by Stuliansky stream. The CBA is essential to evaluate flood damages in the areas. Results from the flow modelling are of great importance for the field of science and practice that their interests are oriented to the proposal of flood mitigation measures in the studied territory.

Keywords: ArcGIS, flood risk modelling, HEC-RAS.
\end{abstract}

\section{INTRODUCTION}

Recent floods in Europe have displaced half a million people and caused more than 25 billion $€$ in insured economic losses. Such flooding impacts are driven in part by increasing hydroclimatic extremes, but also by widespread reliance on structural measures for flood-control [1]. Structural measures to reduce negative impacts of floods include constructing new or reinforcing existing flood defenced infrastructures. There are, however, other and potentially very cost-effective ways of achieving flood protection which profit from nature's own capacity to absorb excess waters [2].

To identify flood areas, a model is required to predict spatially distributed estimates of the hydraulic variables such as flood inundation extent and depth. 1D, 2D and 3D dimensional hydraulic models are now widely used for this purpose. These models are able to compute water surface profiles rapidly in several different characterizations of the system. Recently developed tools for hydraulic modelling (e.g. Geographical Information System (GIS)) are techniques that allow one or two-dimensional representation of the computed hydraulic parameters. In hydraulic modelling, three critical factors: streamflows (flood magnitudes), topography of river channel, and Manning roughness coefficient $\mathrm{n}$ (friction effects) influence flow hydraulics and the resultant areal extent of the simulated flood inundation.

Reducing human casualties and damage to economic activity and the environment are key objectives shared by all EU countries. The economic analysis of how to achieve a suitable 


\section{Flood Risk Management and Response}

water resource management can be achieved by feasibility studies of water management projects. Feasibility studies of projects should be completed by using conventional methodologies of economic analysis, such as cost-benefit analysis (CBA) [3]. The CBA is one of the most widely accepted instruments since it is a rational and systematic decision-making support tool. The impact of a large number of factors should be taken into account in order to assess the financial and economic viability of projects to identify flood prone areas [4].

The paper deals with flood risk modelling of Stuliansky stream in Lopúchov village situated in the north part of Slovakia. The model of Stuliansky stream river bed was developed in HEC-RAS software. The flooded areas in the village were created in ArcGIS using digital terrain model of study area. Precisions proceeding of modelling is described in the following.

\section{MATERIALS AND METHODS}

The aim of this study is to present an efficient methodology for the delineation of the flood hazard mapping. For this purpose, we used HEC-RAS [5] and ArcGIS [6]. These softwares are efficient to state the inundated areas near water stream. Mutual connection of these packages offers to the user a lot of required information. These softwares are very useful for decision making in water management. Advantage of this kind of simulation is efficient (assuming that the needed data is available) visualisation of results and their use in the flood risk management.

Figure 1 illustrates the processing of flood risk modelling which we used to achieve results.

In terms of development of the model it is important to accurately focus on the area of interest in the form of input data. For model development management perspective it is important to properly define the critical points of a given territory in the form of fluvial profiles.

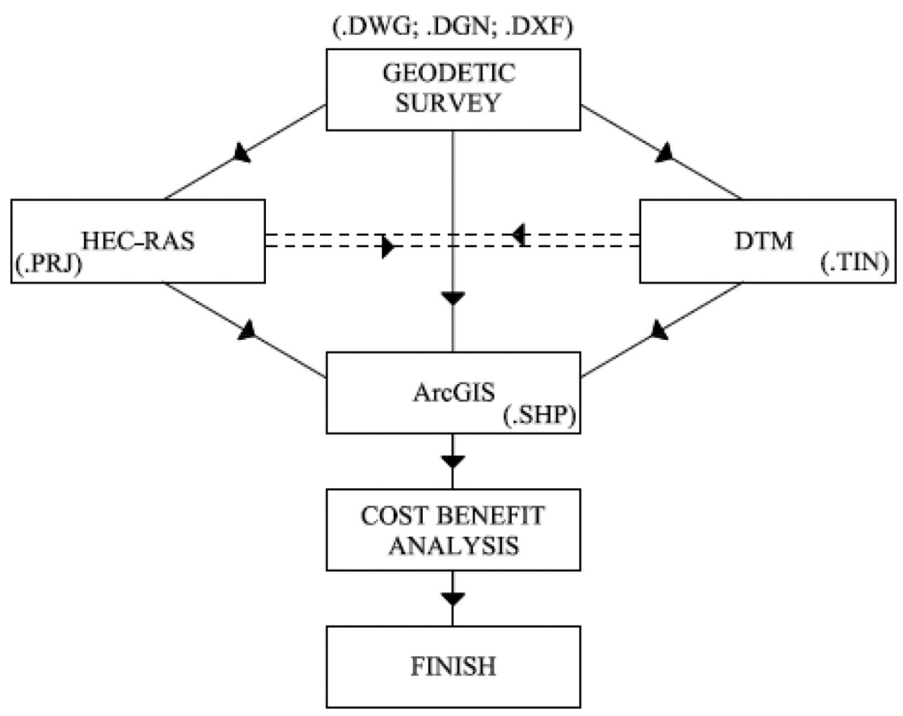

Figure 1: Flowchart of flood modelling. 


\subsection{Geodetic survey}

We chose the area of Lopúchov village (Fig. 2) because of the variability of water flow in Stuliansky stream along its length and the uncontrolled rise of water level during the torrential rains.

The watercourse of Stuliansky stream has the character of a natural stream, river banks are damaged, and river bed is silted after erosion and also due to human intervention. Along the left side of Stuliansky stream is a local road, on the right bank are family houses with gardens [7]. For development of hydrodynamic model the geodetic survey is necessary. We used the output of geodetic survey of the area of interest - Stuliansky stream in Lopúchov village in the north of Slovakia - in various (.dwg; .dgn; .dxf) format (Fig. 3).

Geodetic survey (Fig. 3) of the area served as a base of data for development of hydrodynamic model in HEC-RAS.

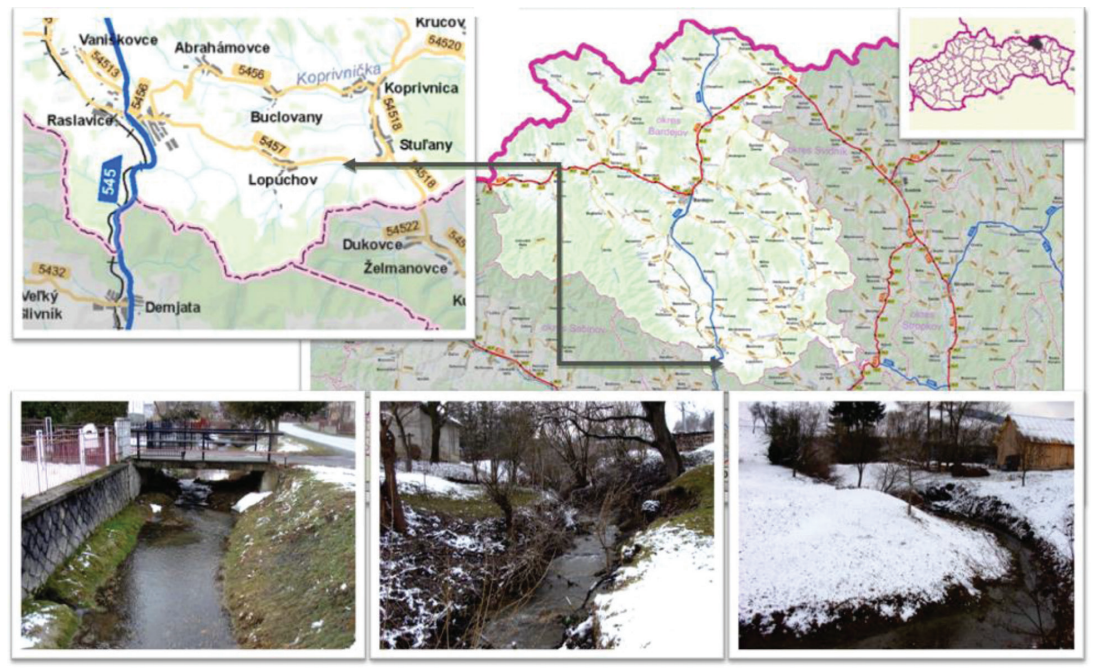

Figure 2: Location of study area.

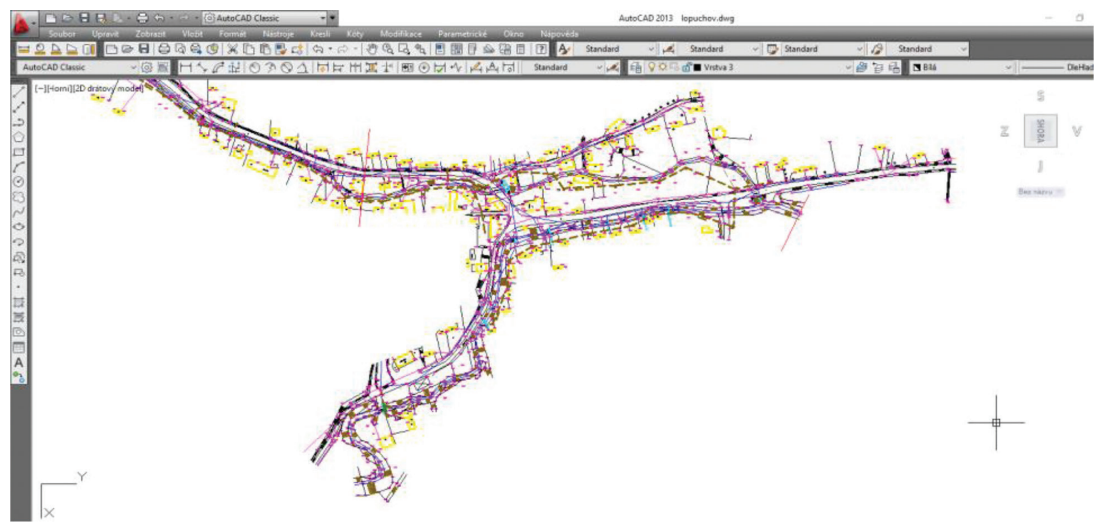

Figure 3: Geodetic survey of Stuliansky stream in Lopúchov village. 


\subsection{Hydrodynamic model in HEC-RAS}

We determined the individual cross sections (Fig. 4) in characteristic locations - approximately each $25 \mathrm{~m}$.

We stated the coefficient of roughness by visual comparison of results published by [8] (Fig. 5).

Selection of an appropriate value of Manning's $n$ is very important for the accuracy of the modelling of the height of water level in the stream The value of Manning's $n$ is variable and depends on a number of factors including: surface roughness; vegetation; channel irregularities; channel alignment; scour and deposition; obstructions; size and shape of the channel; stage and discharge; seasonal changes; temperature; and suspended material. In general, Manning's $n$ values should be calibrated and values of $n$ computed for similar stream conditions or values obtained from experimental data should be used as guides in selecting the proper $n$ values [9].

The objects on the stream (Fig. 6) - in our case bridges - were also defined in the model as the objects influence the flow of the stream significantly.

After cross sections definition (Cross Section Data) and coefficients of roughness determination, we state boundary conditions (Steady Flow Data) as variant values of $N$-year flows. Such a model is ready for simulation (Steady Flow Analysis) of flood wave [10].

The partial result of the computing process is the height of the water level in each river profile. Figure 7 shows the height of water level by flow $Q_{1}=0.04 \mathrm{~m}^{3} \cdot \mathrm{s}^{-1}$ in the whole reach of the river. The results from modelling in HEC-RAS can be exported to the prepared digital terrain model (DTM) model.

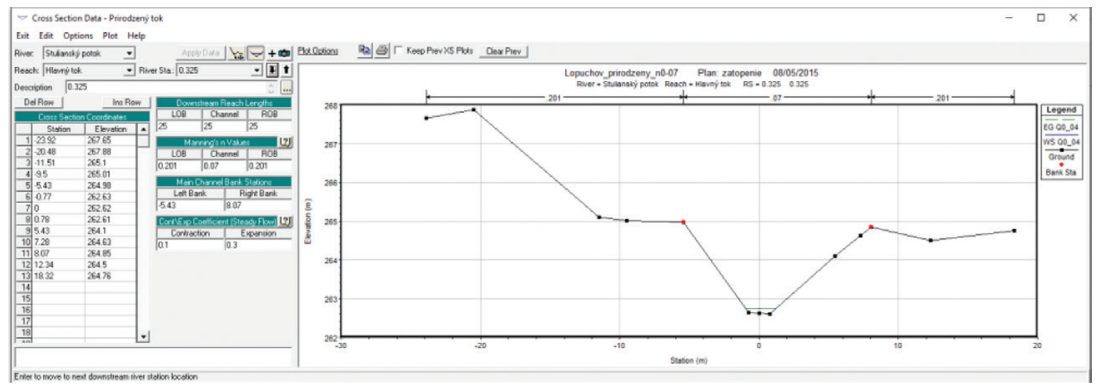

Figure 4: Example of cross section of Stuliansky stream.

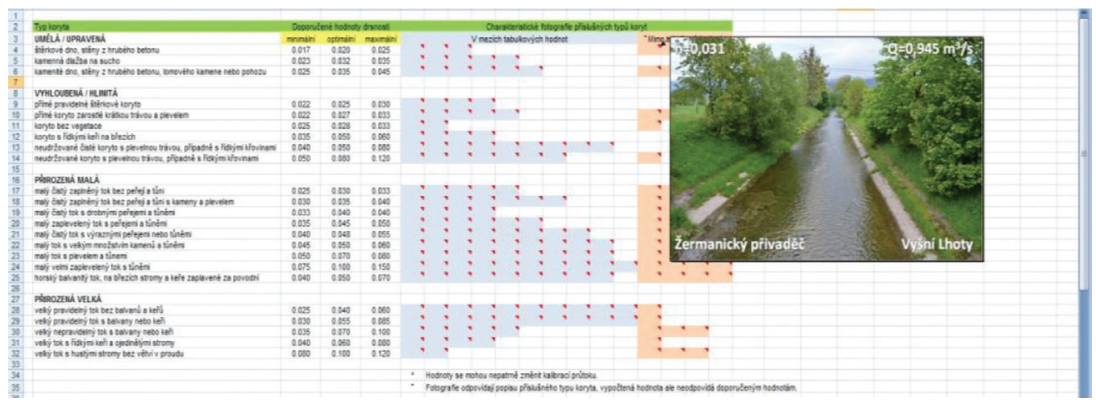

Figure 5: Coefficient of roughness for various streams. 


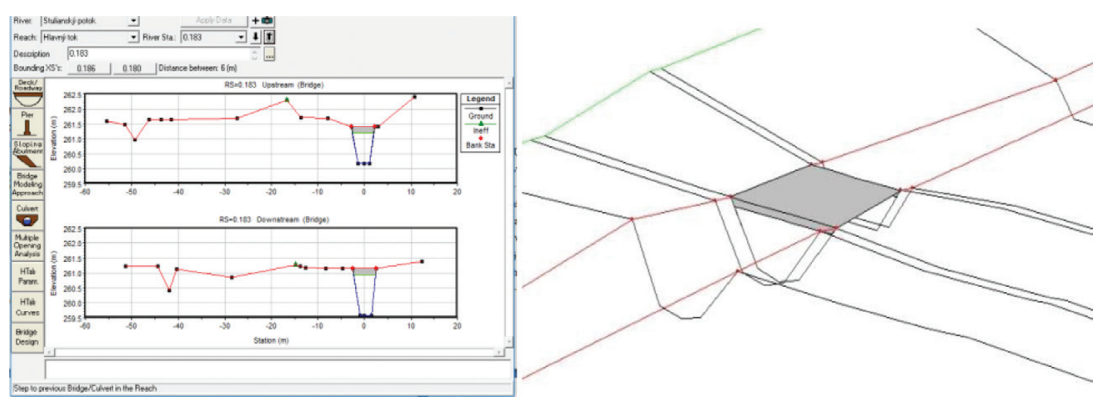

Figure 6: Defining of a bridge object.

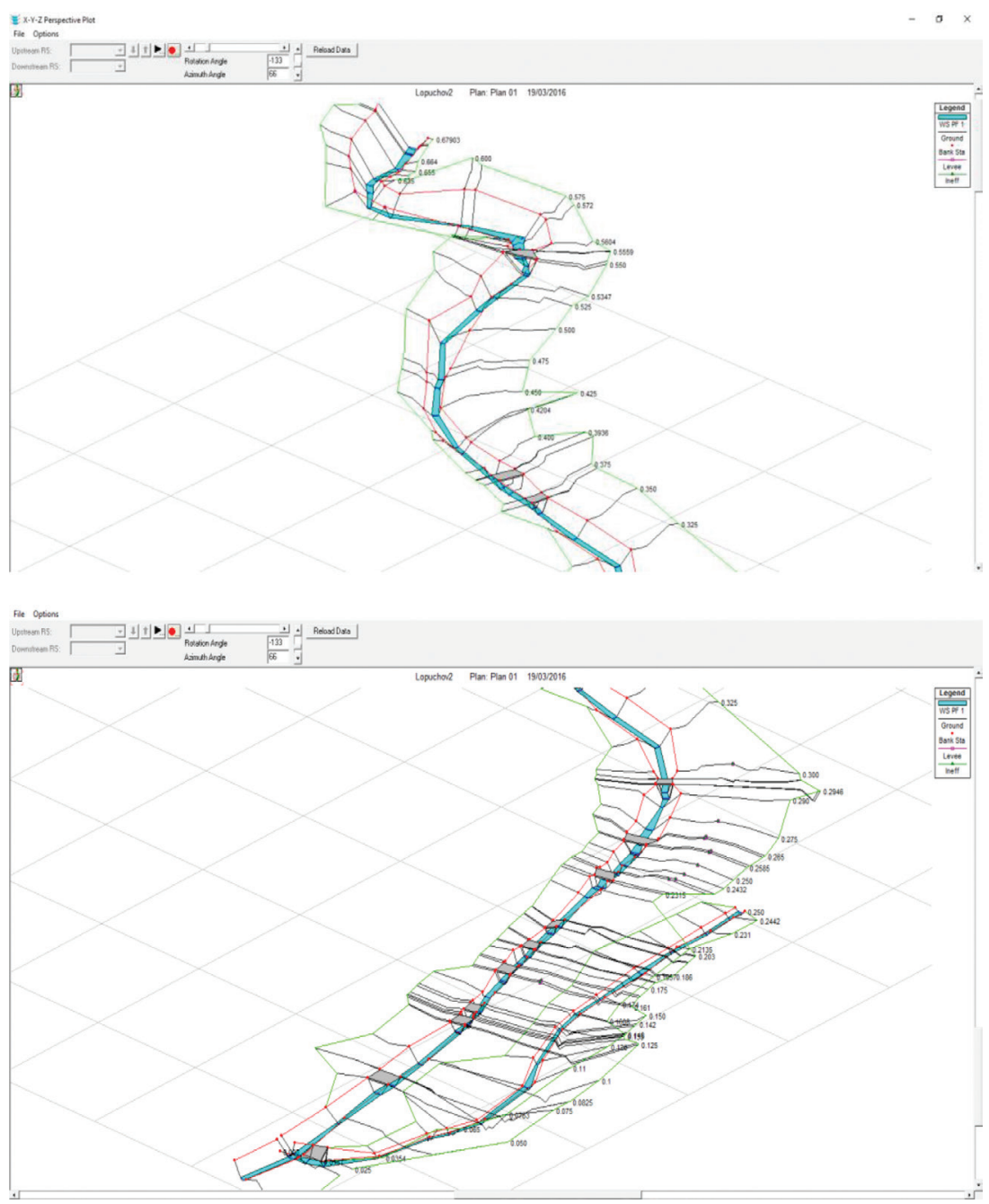

Figure 7: 1D model of Stuliansky stream in HEC-RAS $\left(Q_{1}\right)$. 


\subsection{Digital terrain model in ArcGIS}

We used the trigonometric measurement of altitudes from geodetic survey to create a DTM model. We reflected the elevation of point's data in the triangulation form and we created a ground surface using ArcGIS software (Fig. 8). Then we used the created DTM (Fig. 9) as a basis for visualizing the obtained results.

We obtained the flooded areas near Stuliansky stream in Lopúchov village by connection of developed model in HEC-RAS and DTM in ArcGIS software.

\section{RESULTS}

We prepared separate layers for flood risk modelling in (.shp) form from geodetic survey of Stuliansky stream and objects (houses, roads ...) in the study area. By overlaying of the layers, we created manually in ArcGIS: 'Layer Properties $\Rightarrow$ Base Heights' and we used 'Floating on a custom surface'. Then we put to layers the coordinate system of the area and connected them with DTM (.tin) and model from HEC-RAS. We created Z-coordinate for 3D visualization by 'Layer Properties $\Rightarrow$ Extrusion'. The result is 3D model of the study area with separate layers (Fig. 10).

Figure 11 shows the model with results of $Q_{100}$ water using hydrodynamic model in ArcGIS. By this way we can define any flow of water as boundary conditions and to identify the total surface of inundation area.
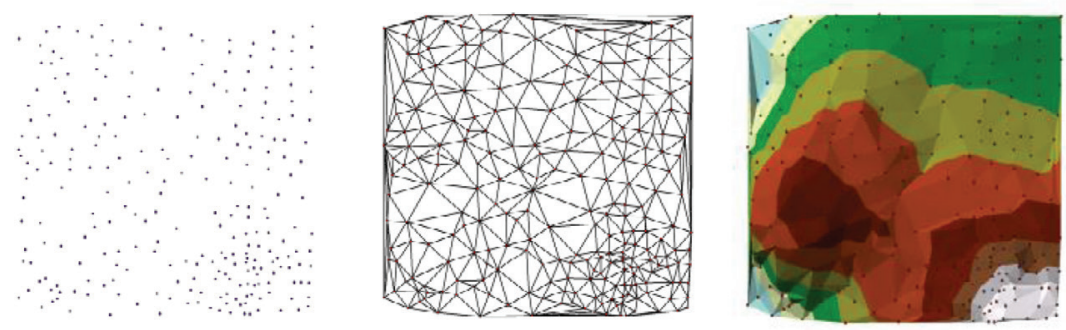

Figure 8: Process steps: Data - Triangulation - Terrain model.

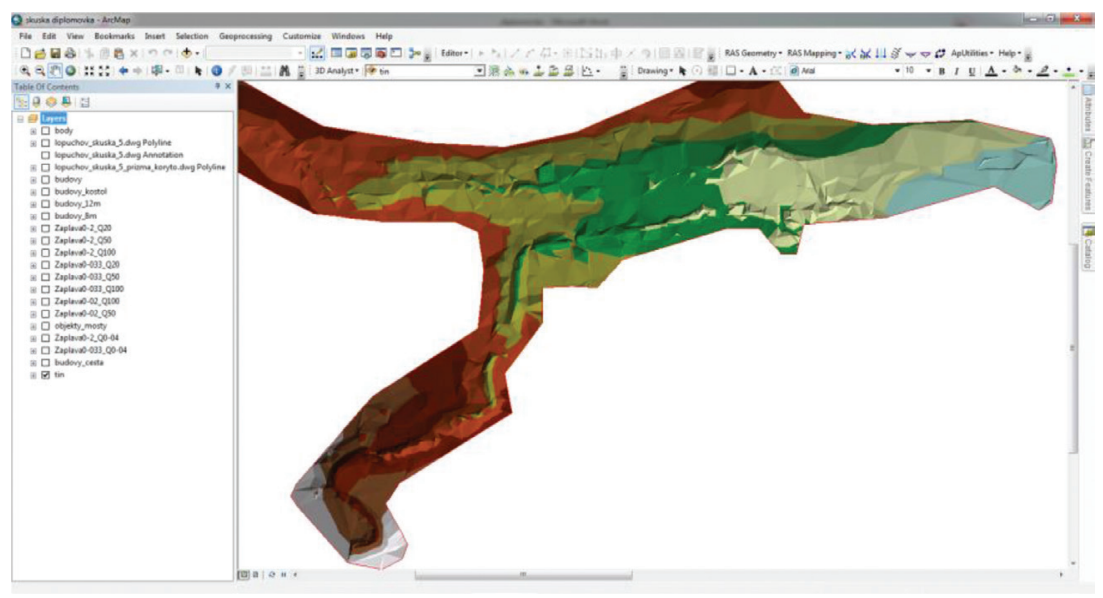

Figure 9: Digital terrain model created in ArcGIS software. 


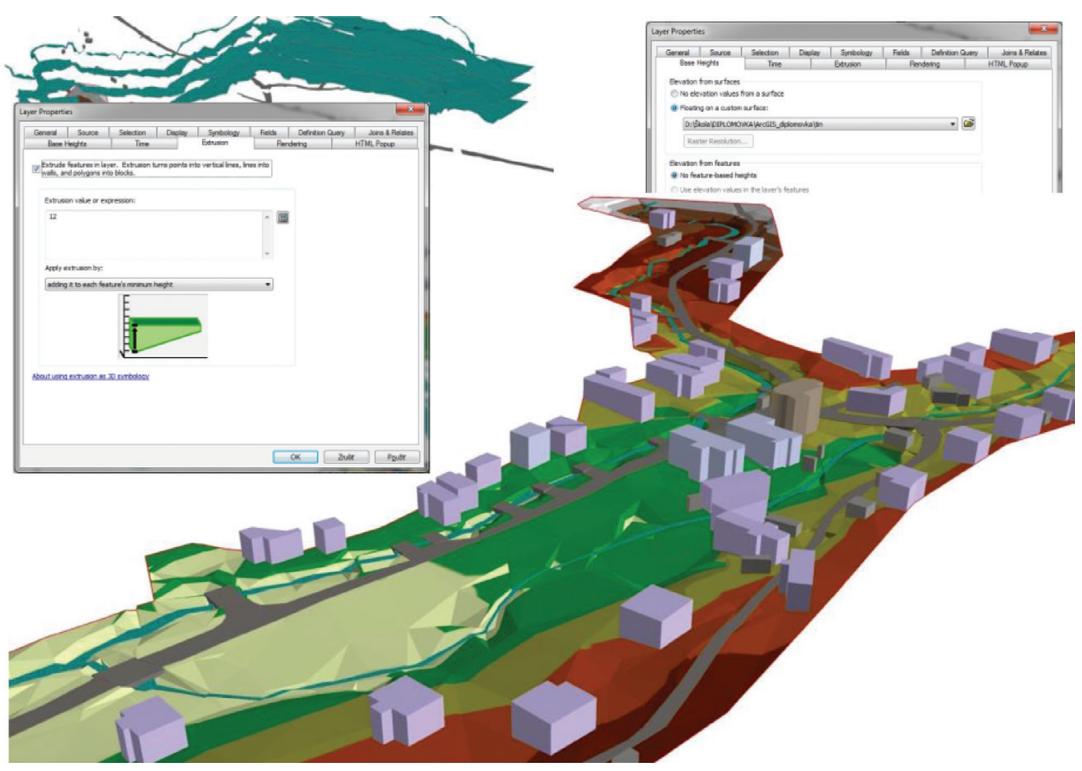

Figure 10: 3D model of the study area with separate layers.
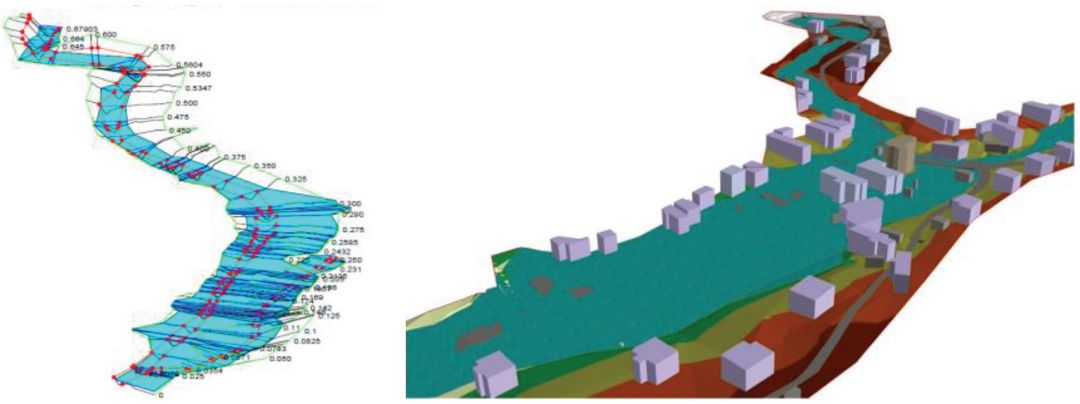

Figure 11: Flooded area by $Q_{100}$.

The flooded area is used as background for CBA. From the flooded area by 100 -year river discharge ' $Q_{100}$ ', the potential flood damages could be identified. For the purpose of flood risk management, the costs of damages were compared with the costs of structural flood protection measures. The construction costs of stream regulation and banks fortification or protection levees have to be less than potential flood damages in the area. It is the core of CBA. We calculated potential flood damages in the study area for $977,735.00 €$. Unit cost of damaged property was calculated to be $100 € / \mathrm{m} 2$ for roads and $525 € / \mathrm{m} 2$ for building structures. The values were stated from UNIKA 2012: Collection of indicators of average budget value per measured unit for object. Buildings and constructions according to the structure classification [11], where the recommended minimum and maximum prices of engineering activities are determined.

\section{CONCLUSION}

Flood damages that arose on rivers, streams and hydraulic structures on the territory of Slovakia are huge. Under the influence of long-lasting and intensive precipitations, numerous 
floods arise. The water levels in many profiles on streams reached its historical maximums in the last years. Regular occurrence of floods in Slovakia occurs primarily by total land water regime, which is dominated by very low absorptive power of heavy clay soils of flysch zone and also adverse condition of forests in eastern Slovakia. Flood risk modelling is an effective tool for flood protection before flood mitigation measures implementation.

We used 1D HEC-RAS model and 2D and 3D model developed in ArcGIS to determine flood areas near Stuliansky stream in Lopúchov village. 1D mathematical model developed in HEC-RAS is very effective for the design of the proposed flood mitigation measures. It is appropriate and excellent tool for hydrodynamic modelling for water managers. However, for a visual presentation of the results to the public, it is more suitable to use results from $3 \mathrm{D}$ modelling in ArcGIS.

Inundation area of the village Lopúchov is quite extensive and flood protection measures (regulation of water stream) in the study area is necessary. The results of our work proved that the costs of structural flood protection measures have to be less than 977,735.00 €, which is the amount of potential flood damages in the study area. Creation of the hydrodynamic model will help in decision making of the selection of suitable flood mitigation measures in term of cost-effectiveness.

\section{ACKNOWLEDGEMENTS}

This paper was written thanks to support from project VEGA 1/0609/14.

\section{REFERENCES}

[1] European Commission, Floods and their impacts, A European Flood Action Programme. 2014, available at: http://ec.europa.eu/environment/water/flood_risk/impacts. htm, (accessed 02 March 2016).

[2] European Commission, Best practices on flood prevention, protection and mitigation, 2003., available at http://ec.europa.eu/environment/water/flood_risk/pdf/flooding_bestpractice.pdf, (accessed 23 March 2016).

[3] Molinos-Senante, M., Hernandez-Sancho, F. \& Sala-Garrido, R., Cost-benefit analysis of water-reuse projects for environmental purposes: a case study for Spanish wastewater treatment plants. Journal of Environmental Management, 92(12), pp. 3091-3097, 2011.

[4] Djukic, M., Javanoski, I., Munitlak, O.I., Lazic, M. \& Bodroza, D., Cost-benefit analysis of an infrastructure project and a cost-reflective tariff: A case study for investment in wastewater treatment plant in Serbia. Renewable and Sustainable Energy Reviews, 59(6), pp. 1419-1425, 2015.

[5] U.S. Army Corps of Engineers. (2014). HEC-RAS River Analysis System, HEC-RAS 4.1. Institute for Water Resources. Washington DC, available at: http://www.hec.usace. army.mil/software/hec-ras/, (accessed 25 January 2016).

[6] ESRI. ArcGIS Desktop. Tools for Authoring, Editing, and Analyzing Geographic Information, available at: http://www.digitalgeo.pt/images/Produtos/31/ef02a26d-ae474b6d-b8a4-53133cc14a12.pdf, (accessed 25 January 2016).

[7] Zeleňáková, M., Sarka, D., Zvijáková, L. Preventívne protipovodňové opatrenia Úprava vodných tokov v obci Lopúchov. Zámer, 2011.

[8] Smelík, L., Katalog drsností. Ústav vodních staveb, Fakulta stavební, VUT v Brně, available at: http://sites.google.com/site/katalogdrsnosti/6-vypocet-drsnosti (accessed 23 January 2015). 
[9] Sánchez, F.J. \& Román, S., Manual introductorio a HEC-RAS. Departamento de Geología, Universidad. Salamanca, España, 2007.

[10] Horritt, M.S. \& Bates, P.D., Predicting floodplain inundation; rastered-based modelling versus the finite-element approach. Hydrological. Processes, 15(5), pp. 825-842, 2001.

[11] UNIKA, Collection of indicators of average budget value per measured unit for object. Buildings and Constructions According the Structure Classification, Institute of Construction Economics: Bratislava, 2012. 